\title{
Klasik kemençe eğitiminde halk ezgilerinden faydalanmanın yolları; Hisarlı Ahmet türküleri örneği
}

\section{Ways to benefit from folk songs in classical kemenche training; example of Hisarli Ahmet's folk songs}

\section{Filiz Kaya Işık}

Dr., Bağımsız Araştırmacı, TÜRKIYE, e-mail: filizkaya@yahoo.com

Öz

Mesleki çalgı eğitiminde sistemli bir metot uygulamasının yanında, çalgının ses sahasına, teknik özelliklerine ve ses tınısına uygun repertuvar seçimi de büyük önem taşımaktadır.

Klasik kemençe eğitiminde, istenilen ölçüde sistemli metot çalışması bulunmamaktadır. Bununla birlikte yine klasik kemençeye uygun sistemleştirilmiş, özel notasyona sahip yeterli sayıda dağar da yoktur.

Müzik eğitiminin birçok safhasında halk ezgileri kullanılmaktadır. Klasik müziklerin geleneksel müziklerden beslenmesinden yola çıkarak, klasik kemençe eğitiminde de türkülerimizden faydalanmak mümkündür.

Bu bağlamda araştırmanın amacı, Hisarlı Ahmet türkülerinin, klasik kemençe çalım teknikleriyle işlenerek eğitim repertuvarına kazandırılması ve Hisarlı Ahmet türkülerinin klasik kemençe ile akademik düzeyde, sistemli olarak icra etme ve üslup ile yorumlama yöntemlerinin araştııılmasıdır. Verileri toplamak için literatür taraması yapılmıştır. Türkiye Radyo Televizyon (TRT) Kurumu repertuvarında yer alan Hisarlı Ahmet türküleri taranmış ve bu türkülerden klasik kemençe eğitimi için seçilen beş türkü, örneklem grubu olarak ele alınmıştır. Türkülerin makamsal ve ritimsel yapıları incelenmiş, notalar üzerinde sağ el teknikleri (yay teknikleri; Detaşe, legato, staccato, tremola, pizzicato vb.) ve sol el teknikleri (pozisyonlar, vibrato, glisando, çarpma vb.) yazılarak klasik kemençe eğitimi için uygun hale getirilmiştir. Yapılan bu çalışmalar alanında uzman olan üç eğitimci ile paylaşılmış ve onların görüşleri doğrultusunda gerekli görülen düzeltmeler yapılmıştır. Seçilen türkülerin notasyona uygun icrası youtube sosyal medya platformuna yüklenmiş ve herkes tarafından ulaşılır olması sağlanmıştır.

Türkülerin notaya alınması ve düzenlenmesinde 'Mus 2' programı kullanılmıştır.

Anahtar kelimeler: klasik kemençe, çalgı eğitimi, Hisarlı Ahmet, türkü, dağar.

Citation/Atıf: KAYA IŞIK, F., (2021).Klasik kemençe eğitiminde halk ezgilerinden faydalanmanın yolları; Hisarlı Ahmet türküleri örneği. Journal of Arts. 4(3): 189-202, DOI: 10.31566/arts.4.3.06

Corresponding Author/ Sorumlu Yazar Filiz Kaya Işık

E-mail: filizkaya@yahoo.com
Bu derginin içerĭği Creative Commons Attribution-NonCommercial 4.0 Uluslararası Lisansı altında lisanslanmıştır.

Content of this journal is licensed under a Creative Common Attribution-NonCommercial 4.0 International License. 


\begin{abstract}
Choosing a repertory coherent with the register, technical properties and the timber of the instrument, along with applying a systematic methodology, is quite important in professional music education.
\end{abstract}

Today, the Turkish Music instrument education, as well as the European Music instrument education, still lacks systematical methods and repertories designed specifically for different instruments.

In classical kemenche education, not only there are not enough systematic methodology studies, but also the number of repertories systematized according to classical kemenche with special notation is insufficient.

The traditional tunes are being used in many phases of music education. Concerning how classical music makes use of traditional music, we may argue that we can also make use of folk music in classical kemenche education.

The general aim of this search is to provide academic level research of systematic and scientific methods of performing and playing of Hisarlı Ahmet's folk songs with a classical kemenche which is a traditional instrument. Both for this purpose the data collecting used in the research, as well as accessing the resources that make up Hisarll Ahmet's folk songs a literature review conducted, Hisarl Ahmet's folk songs from the repertoire of the Turkish Radio and Television(TRT) institution were scrutinized and from these studied folk songs five of them considered suitable for classical kemenche training as handled as sample groups.

In this context, this study will choose five works of Hisarlı Ahmet through a study of their modal and rhythmical structures and will provide a special notation for classical kemenche via identifying the bow and performance techniques of these works. These studies were shared with some experts in their field by making necessary corrections following their views. This study aims to bring these five works in classical kemenche education and concert repertory by providing a notation peculiar to kemenche. Folk songs have been uploaded to the youtube social media platform and made accessible to everyone.'Mus 2' was used to note and edit folk songs.

Keywords: classical kemenche, instrument education, Hisarlı Ahmet, folk music, repertory.

\section{GİRIŞ̧}

Bu bölümde; Hisarlı Ahmet ve türküleri, müzik eğitimi ve çalgı eğitimi, klasik kemençe eğitimi, problem durumu, araştırmanın problemi, alt problemleri, araştırmanın amacı, araştırmanın önemi, varsayımlar ve sinırlılıklar gibi kavramlara yer verilmiş ve açıklamalarda bulunulmuştur.

XX. yüzyılın ilk yarısında yabancı araştırmacılardan Bela Bartok, Zoltan Kodaly, Mozer, Brenet, Prat, Breniers, Türkler'den Mahmut Ragıp Gazimihal, Halil Bedi Yönetken, Muzaffer Sarısözen ve Nida Tüfekçi gibi müzikologlar tarafından yapılan tanımlamalarda birleşilen ortak düşüncelere göre halk musikisi; Sahibinin kim olduğu bilinmeksizin halkın ortak malı halinde yaşayan bu yönüyle de anonim kabul edilen eserlerdir. Bunlar halkın ortak değerlerini terennüm eden derin bir geçmişe ve coğrafya ile bağlantılı yayginlığa sahiptir (Şenel,1995:354)

Türküler; zaman içerisinde, her coğrafyaya özgü ritim ve ezgi yapılarıyla bezenerek, insana ait yaşanan ne varsa, an be an hayata geçmiş melodilerdir. Aşık edebiyatı ile sözsel anlatım ustalığını gösteren türkülerimiz, yaşama dair ne varsa dizelerinde barındırır ve üzerlerinde kültürel kodlar taşırlar.

Ege Bölgesi aşıklarının içinde dikkati çeken Hisarlı
Ahmet, yaktığı türküleriyle bu kültürel zenginliği beslemiştir.

\subsection{Hisarlı Ahmet ve Türküleri}

Kütahya folklorunun ve yaşam tarzının zenginliği sanat camiasının ortak görüşüdür. El sanatlarındaki oya, gergef, sırma işlemeleri, çini işlerindeki incelik ve zerafet, türkülerde de kendini gösterir. Melodik yapının kıvraklığı, genişliği, ritim farklılıkları, sözlerindeki duygu ifadelerinin açıklığı halk oyunlarında da görülür. Aynı oyunlu türkülerde erkeklerde sertliği mertliği hissederken, hanımlarda inceliği zerafeti naifliği görürsünüz (Hisarlı,2009:137).

Kütahya türkülerini incelediğimizde, hem melodik yapı olarak hem de ritmik yapı olarak gösterdiği çeşitlilik dikkat çekicidir. Yörenin kültürel zenginliği saza ve sözlere yansımış, aşıklar melodileri adeta oya gibi işlemişlerdir.

Tüm bu güzellikleri özümseyen, sazı sözü ve icrasıyla yaşayan ve yaşaması için gayret gösteren Hisarlı Ahmet sözü edilen kültürel mirasın farkında olmuştur. Yaşadığı dönemde Kütahya ilinin kültürel mirasına sahip çıkmış, gelecek kuşaklara aktarılmasında önemli bir görev üstlenmiştir. Sadece bu özelliği bile O'nu diğerlerinden farklı kılmaktadır. Hisarlı Ahmet, sazı tavrı, üslubu ile Kütahya müzik kültürünün en önemli 
yapı taşlarındandır (Türkmen,2013:26).

Seksen yıllık bir ömre onlarca türkü sığdıran, kendi kültürüne hizmet eden Hisarlı Ahmet, Türk halk müziğinin önemli değerlerinden biri olarak müzik tarihi sahnesinde yerini almıştır.

1908'de Kütahya, Yukarı Hisar'da, Ayşe Hanım ile Mustafa Bey'in ikinci oğulları olarak dünyaya geldi. Gençlik döneminde; gençlerin evlerde toplanarak eğlendikleri ve sohbet ettikleri “Gezek"'lerde üç telli bağlama ile tanıştı. O dönemin ustalar Dülgerin Hüseyin Ağa ve Çerkezlerin Ethem Efendi'den etkilendi ve dersler aldı. Askerlik çağında klarnet çalmayı ve okuma-yazmayı öğrendi. Askerlik dönüşü evlendi ve şehir merkezine taşındı. Şehir merkezine taşınmasıyla meslek değiştirdi ve kahvehane açtı. Kahvehanesi Aşık Veysel, Aşık Davut Sulâri gibi ozanların; Yücel Paşmakçı, Nida Tüfekçi, Özay Gönlüm, Muzaffer Akgün gibi ses ve saz sanatçllarının ve onu dinlemeye gelenlerin uğrak yeri oldu. Burada hevesli gençlere ücretsiz ders verdi ve çalışmalarını sürdürdü. Muzaffer Sarıözen'in daveti üzerine Ankara Radyosu'na gitmiş ve radyoda kalması teklif edilmiştir. "Hacı" olduktan sonra "Elini eteğini çek bu işlerden" diyenlere "Ben sazımla Rabbime sizden daha yakınım" demiştir. Kavaflık yaptığı yıllarda sık sık İnegöl'e gitmesinden dolayı "İnegöllüoğlu" olan soyadı yerine yörede "Hisarlı" olan lakabını soyadı olarak almıştır. 4 Ocak 1984'te ölmüştür (Hisarlı,2009:137-143).

Hisarlı Ahmet yaşadığı süre boyunca birçok ozan ile meşk etmiş ve onlardan feyz almıştır. Zaman içerisinde kendine has bir bağlama ve söyleyiş tavrını benimsemiştir. Türkülerindeki uzun nefesli pasajlar, geniş ses sahasına sahip melodi örgüleri ve kendine özgü ritim yapıları onun müzik karakteri haline gelmiştir.

Hisarlı'nın icrasındaki tavır yaşadığı Batı Anadolu Bölgesi'nde var olan "zeybek tavrı" ile uyumlu bir "süpürme" tavrıdır. Hisarlı Ahmet, yöresinin insanının türkülerini ve söyleyiş tavrını benimsemiştir. Bu bölgesel tavırla beraber türkülerinin tamamı dinlendiğinde kendine has bir özel tavrının da olduğu kolayca anlaşılır. Ayrıca türküleri seslendirmedeki çok özel ağız yapısı, sanki ağzında bir lokma ekmek ya da sakız varmış da öyle söylüyormuş hissi ile birlikte sesindeki ton, Hisarlı'yı Hisarlı Ahmet yapan en önemli özelliklerindendir. Bağlamasında sağ eli ile taradığ teller sonraları "süpürme" olarak tanımlanmış ve Hisarlı'nın en belirleyici tavır özelliklerinden bir uygulama olarak nitelenmiştir (Yaltırık,2009:83-84).
Hisarlı Ahmet'in TRT repertuvarındaki türkülerini incelediğimizde karşımıza çıkan en çarpıcı özellikler kendine özgü melodi ve ritim zenginliğidir. 27/8'lik 7/4'lük gibi farklı ritim yapıları, türkülerin ezgi diziliminde Klasik Türk müziği makam seyirlerini barındırması, büyük usullerin kullanılması, Hisarlı'nın adeta makam bilgisi olduğunu düşünmemize sebebiyet verecek kadar yoğundur. Zeybek (9/4'lük) formundaki türkülerinde ise yine kendine özgü bir zeybek karakteri kullandığı gözümüze çarpar.

\subsection{Müzik Eğitimi ve Çalgı Eğitimi}

Yalın ve özlü anlamıyla eğitim, bireyin davranışında kendi yaşantısı yoluyla ve kasıtlı olarak istendik değişme meydana getirme sürecidir (Ertürk,1979:12). İnsan eğitime ihtiyaç duyan tek varlıktır (Kant, 2006). Eğitim, kişinin kendisini ve dünyayı olduğu gibi görmesini sağlarken, ona (dünyasına) kendi düzeyinde yaşanabilir kılan donanımları sağlar. Bilim, sanat, felsefe gibi kişiyi donatan ve yaşadığı dünyayı anlamlı kılan alanlar, eğitim sayesinde kazanılır.

Sanat eğitimi, bireyin kişisel gelişimine en etkin şekilde kazanım sağlayacak eğitim alanlarının başında gelir. Sanatın bir dalı olan müzik eğitimi ise, insanın doğasında var olan sessel algılamaya ve bunların kullanılmasına ilişkin özelliklerin, biçimlendirilmesine ve geliştirilmesine dayandığı için, en doğal ve her ortamda rahatlıkla çeşitli etkinliklerle gerçekleşen bir süreçtir.

Müzik eğitimi, bireye kendi yaşantısı yoluyla amaçlı olarak belirli müziksel davranışlar kazandırma, bireyin müziksel davranışında kendi yaşantısı yoluyla amaçlı olarak belli değişiklikler oluşturma, ya da bireyin müziksel davranışını kendi yaşantısı yoluyla amaçlı olarak değiştirme sürecidir (Uçan, 1997).

Müzik eğitiminin boyutlarını; ses eğitimi, müziksel işitme eğitimi, müzik beğenisi eğitimi, yaratıcılık eğitimi ve çalgı çalma eğitimi olarak ele alabiliriz.

Çalgı eğitimi, çalgı çalmanın gerçekleşmesi ve çalgıyı seslendirmek için bireyin davranışlarında teknik ve estetik nitelikli yeni davranışlar geliştirmek amacıyla uygulanan süreçlerin tümüdür. Çalg1 öğretim sürecinde bilgi beceri kazanılır ve davranış geliştirilir, böylece estetik anlayış gelişir ve müziksel kişilik oluşumu sağlanır (Demirbatır, 1998:20).

Türk müziği çalgı eğitimi, 20.yy'ın başlarına kadar usta-çırak, meşk (öğretmen-öğrenci) ve kendi kendine öğrenme gibi geleneksel öğretim yöntemleri ile 
yapılmıştır.

Çoğunlukla nota kullanmadan hafızaya dayalı olarak yapılan eğitimle bizlere ulaşmış olan müziğimizi, bilgi çağının gereği olarak her yönü ile bilimsel temellere oturtmamız gerekmektedir (Yahya, 1997:74).

Mesleki çalg1 eğitiminde sistemli bir metot uygulamasının yanında, çalgının ses sahasına, teknik özelliklerine ve ses tınısına uygun repertuvar seçimi de büyük önem taşımaktadır. Bugün Türk Müziği çalg1 eğitimi, halen Avrupa müziği çalg1 eğitiminde olduğu gibi her çalgıya özel sistemli metotlara ve tam anlamıla çalgıya özel bir dağara sahip değildir. Bunun en önemli sebebi kuşkusuz ki Türk müziğinin büyük oranda sözlü bir repertuvara sahip olmasıdır. Türk saz müziği 19.yy ikinci yarısı itibari ile Kemani Sebuh (?-1890), Lavtac1 Andon (?-1925), Santuri Ethem Efendi (1855-1926), Kemençeci Nikolaki (?-1915), Tatyos Efendi (1858-1913), Muallim İsmail Hakkı Bey (18661927) vb. gibi değerli isimlerle gelişmeye başlamıştır. 20.yy'da ise çalgıya özel eser besteleme örnekleri karşımıza çıkmaya başlarmıştır. Tanburi Cemil Bey (1871-1916), Refik Fersan (1893-1965), Şerif Muhittin Targan, Refik Talat Alpman(1894-1947), Haydar Tatlıyay (1890-1963), Sadi Işılay (1899-1969), Reşat Aysu (1910-1999), Cinuçen Tanrıkorur (1938-2000) gibi bestekarlarla öne çıkan çalg1 müziği besteciliği, günümüzde de Necdet Yaşar, Alâettin Yavaşça, Göksel Baktagir, Yurdal Tokcan, Murat Aydemir vb. gibi önemli isimlerle varlığını sürdürmektedir.

Akademik eğitimin yaygınlaştığı günümüzde mesleki çalgı eğitimi için sistemli çalgı metotları, etüt kitapları ve çalgıya özel eser besteleri istenilen boyutta olmasa da yapılan çalışmalar her geçen gün çoğalmaya devam etmektedir.

\subsection{Klasik Kemençe Eğitimi}

Yüzlerce yıllık bir tarihe sahip Türk Müziği'nde kendine önemli bir yer bulmuş klasik kemençe sazının, günümüze kadar gelen eğitim sürecine bakıldığına, 20.yy'ın neredeyse son çeyreğine kadar geleneksel eğitim yöntemleri kullanılarak öğretildiğine tanık olmaktayız. Bu yöntemleri usta-çırak ilişkisi, meşk usulü (öğretmen-öğrenci) ve kendi kendine öğrenme yöntemi olarak sıralayabiliriz.

Arapça bir kelime olan meşk, Türk-İslâm sanatlarında bir hocanın talebeye taklit ederek öğrenmesi için verdiği ders ve örnekleri ifade etse de; bunun dışında birlikte çalışmayı da karşılamaktadır (Serin,1995:374). Türk mûsikîsinde meşk, hoca ve talebesinin birlikte çalışmaları suretiyle sözlü eserler ve saz eserleri repertuvarının yüzyıllar boyu nesilden nesile intikalini sağlamış bir eğitim ve öğretim sistemidir. XIX. asrın ilk çeyreğine kadar Türk mûsikîsi öğretimi tamamen bu sisteme dayalı olarak devam etmiş, daha sonraları Batı etkisiyle kurulan konservatuvar vb. mûsikî kurumlarında da meşk kısmen uygulanmış olup günümüzde de belirli ölçülerde sürmektedir (Özcan,1995:375).

Klasik kemençe eğitiminde halen öğretim yöntem ve tekniklerini tam anlamılla kullanan ve bizlere kılavuz olacak nitelikte yeterli sayıda metot yoktur. Günümüz şartlarında çalgı eğitimini akademik ortamda ele almak, çağın gerektirdiği nitelikleri sağlamak ve geliştirmek zorundayız. Türk müziği çalgı eğitiminin her alanında sistemli metot çalışmaları çoğaltılmalı ve çalgıya özel repertuvar konusuna önem verilmelidir.

Yapılan araştırmalar sonucunda görüyoruz ki klasik kemençe, dünya üzerinde Anadolu, Bulgaristan, Yunanistan, Romanya, Macaristan gibi farklı coğrafyalarda, gadulka, lyra, hedegü, armudi kemençe, tırnak kemençe, tırnak kemane, fasıl kemençesi gibi değişik isim ve formlarda karşımıza çıkmaktadır. Bugün Türk Müziği'nin vazgeçilmez yaylı sazlarından biri olma niteliğini taşımaktadır. Yüzyıllardır icra edilmiş, öğretilmiş ve bundan sonra da öğretilmeye ve icra edilmeye devam edilecektir.

Bu sazın eğitim süreci içerisinde sistemli metot kullanımının yanında her seviyeye uygun etütler yazılmalı ve yardımcı eser repertuvarları hazırlanmalıdır. 
Tablo 1. Klasik Kemençe Eğitiminin Genel Aşamaları

\begin{tabular}{|l|l|}
\hline Doğru oturuş ve tutuş pozisyonu & $\begin{array}{l}\text { Vücudun doğru kullanımı } \\
\text { Sol el tutuşu (Kemençeyi ve bileği doğru } \\
\text { konumlandırma) } \\
\text { Sağ el tutuşu (Yayı doğru şekilde ve doğru } \\
\text { konumda tutma) }\end{array}$ \\
\hline \begin{tabular}{l} 
Doğru yay kullanma \\
\multicolumn{1}{|c|}{ doğru } \\
(Entınlatılması
\end{tabular} & $\begin{array}{l}\text { Aşama aşama yay kullanım teknikleri } \\
\text { Detaşe,Legato,Staccato,Pizzicato,Tremola... }\end{array}$ \\
\hline $\begin{array}{l}\text { Sol el ve modal etütler, yardımcı parçalar } \\
\text { aşama öğretimi }\end{array}$ & $\begin{array}{l}\text { Pozisyon hakimiyeti } \\
\text { Süsleme teknikleri (glisando, vibrato, } \\
\text { çarpma, mordan, grupetto vb.) }\end{array}$ \\
\hline $\begin{array}{l}\text { Nüans kullanımı } \\
\text { Tavır, uslup kazandırma }\end{array}$ & $\begin{array}{l}\text { Yay kullanım teknikleriyle, yaya doğru } \\
\text { baskı şiddeti uygulama }\end{array}$ \\
\hline $\begin{array}{l}\text { Taklit ve dinleme ile kendi yorumunu } \\
\text { oluşturma. }\end{array}$ \\
\hline
\end{tabular}

Klasik kemençe eğitiminde doğru oturuş ve tutuş pozisyonunu öğrenciye kazandırmak ilk adımdır. Sağ el ve sol el tutuş hakimiyeti kazandırdıktan sonraki aşama, doğru yay kullanımı olmalıdır. Doğru yay kullanımı, klasik kemençe eğitiminde ne yazık ki üzerinde yeterince durulmayan bir konudur. Yay1 çalgılarda, nüansları ancak doğru yay kullanımı ile sağlayabiliriz. Bu sebeple klasik kemençe eğitiminde sağ el teknikleri ( Detaşe, legato, Kesik Yay (staccato), pizzicato, tremola) üzerinde tek tek durularak yay hakimiyeti kazandırılmalıdır.

Eğitim sürecindeki başlıklardan biri de doğru perde basma yani seslerin doğru tınlatılmasıdır (Entonasyon). Bunun için de modal/tonal etütler ile birlikte yardımcı parçalar kullanarak öğrenciye doğru perde basma yetisi kazandırılmalıdır. Bu çalışmalar sazın öğrenimi esnasında klasik eserlere geçmeden uygulanması gereken önemli bir süreçtir.

Temel olarak sağ el ve sol el teknikleri oturtulduktan sonra sırası ile pozisyon, süsleme, transpoze ve doğaçlama tekniklerinin öğrenciye aktarılma süreci başlar. Öğrenci bu süreç esnasında ve sonrasında usta icracıları dinleyerek ve taklit ederek zaman içerisinde kendi üslup ve tavrını oluşturacaktır.

\subsection{Problem Durumu}

Çalg1 eğitimi sırasında, çalgı öğretimi repertuvarında önemli bir materyal olarak kullanabileceğimiz halk ezgilerimizden, ne şekilde ve hangi amaçla yararlanıldığı önemli bir noktadır. Özellikle makamsal müzikte makam seslerini öğrenciye kavratma aşamasında, 'meşk usulü' en etkili yöntem olarak kullanılmaktadır. Bu aşamada halk türkülerinin melodik açıdan kulağımızda çabuk yer etmesinden faydalanarak makamsal sesleri öğrenciye kavratmak çok daha kolay olmaktadır.

Klasik kemençe eğitiminin bazı safhalarında halk ezgilerinden yararlanmak mümkündür. Ege bölgesi aşıklarından olan Hisarlı Ahmet'in türküleri hem ezgi hem de ritmik yapıları bakımından incelendiğinde klasik kemençe eğitiminde kullanılabilir özelliklere sahiptir.

Hisarlı Ahmet türküleri, klasik kemençe eğitiminde makamsal aktarım amacı ile kullanılabilirler. Ayrıca bu türküler legato, çarpma, trill, vibrato, grupetto, glisando gibi önemli sağ ve sol el tekniklerinin ileri seviye uygulamalarının çalışılmasına imkan sağlayacak niteliklere sahip oldukları için, ileri seviye klasik kemençe eğitiminde kullanılabilecek ve farklı bir bakış açısı kazandıracak önemli eserlerdir.

Bu bağlamda Türkiye Radyo Televizyon (TRT) Kurumu repertuvarında yer alan Hisarlı Ahmet türküleri incelenmiş ve bu türkülerden klasik kemençe eğitimi için uygun olduğu düşünülen beş türkü seçilerek, makamsal ve ritimsel yapıları incelenmiş, notalar üzerinde sağ el teknikleri (yay teknikleri; Detaşe, legato, staccato, tremola, pizzicato vb.) ve sol el teknikleri (pozisyonlar, parmak numaraları, vibrato, gisando, çarpma vb.) yazılarak klasik kemençe eğitimi için örnek bir dağarcık oluşturulmuştur. 


\subsection{Araştırmanın Problemi}

$\mathrm{Bu}$ araştırmanın problem cümlesi; Klasik kemençe eğitiminde Hisarlı Ahmet türkülerinden faydalanmanın yolları nasıl olmalıdır? Şeklinde oluşmaktadır.

\subsection{Alt Problemler}

Problem cümlesi doğrultusunda aşağıdaki alt problemlere cevap aranmıştır.

- Hisarlı Ahmet türkülerinin seslendirilmesinde klasik kemençe sağ el teknik kullanımını nasıl şekillendiririz?

- Hisarlı Ahmet türkülerinin seslendirilmesinde klasik kemençe sol el tekniklerini nasıl kullanabiliriz?

- Örneklem olarak seçilen Hisarlı Ahmet türkülerini Klasik kemençe eğitiminin hangi aşamalarında kullanabiliriz?

- Hisarlı Ahmet türkülerini konser repertuvarında kullanabilir miyiz?

- Klasik kemençe eğitiminde makamsal seslerin icrasında ve entonasyon çalışmalarında Hisarlı Ahmet türkülerinden nasıl faydalanabiliriz?

- Klasik kemençe eğitiminde usul uygulamalarında Hisarlı Ahmet türkülerinden nasıl faydalanabiliriz?

\subsection{Araştırmanın Amacı}

$\mathrm{Bu}$ çalışmanın amacı; Hisarlı Ahmet türkülerinin akademik eğitim ortamında ve sistemli metot ölçütlerine uygun bir şekilde, klasik kemençe ile seslendirilme ve yorumlanma yöntemlerinin araştırılması ve eğitim programlarında kullanılabilir olmasını sağlamaktır.

\subsection{Araștırmanın Önemi}

$\mathrm{Bu}$ araştırma:

1. Hisarlı Ahmet türkülerinin klasik kemençe çalım teknikleriyle işlenerek eğitim repertuvarına kazandirılması,

2. Klasik kemençe eğitimcilerine ve öğrencilerine kaynak sağlaması,

3. Makamsal aktarım aşamasında etkili bir öğrenme yöntemi oluşturması,

4. Türk Müziği çalgı eğitimindeki sistemli metotlara ve etüt kitaplarına destek olacak mahiyette farklı bir perspektif yaratması,

5. Zeybek formunun klasik kemençe ile icrasının kavranması,

6. Türk Halk müziği icracıları ile birlikte çalışmak için ortak repertuvar oluşturması,

7. Klasik Kemençe ileri seviye ve usta icracılık eğitim süreçlerinde, özellikle sağ ve sol el tekniklerini üst seviyede kullanarak üslup ve tavır çalışması için bir dağar sağlaması,

8. Bundan sonra yapilacak olan bu ve buna benzer başka çalışmalara fikir vermesi ve farklı arayışlara götürmesi, bakımından önemli görülmektedir.

\subsection{Varsayımlar}

1. Araştırmanın örneklemi evreni temsil edecek niteliktedir.

2. Araştırma yöntemleri araştırmanın amacına ve konusuna uygundur.

3. Araştırmada kullanılan teorik bilgiler ve türkülerin seçiminde kullanılan kaynaklar yeterince mevcuttur.

4. Araştırma klasik kemençe eğitmenleri ve öğrencilerine kaynak teşkil edecek niteliktedir.

5. Araştırmada kullanılan Hisarlı Ahmet türküleri klasik kemençe eğitiminin gelişmesine katkıda bulunacak, çeşitli sağ ve sol el tekniklerinin üst seviyede uygulanmasına imkân sağlayacak niteliktedir.

6. Araştırma benzer çalışmalara katkı sağlayıp yön verecek niteliktedir.

\subsection{Sinırlılıklar}

Araştırma;

1. Türkiye Radyo ve Televizyon Kurumu (TRT) repertuarında yer alan beş Hisarlı Ahmet türküsü ile,

2. Araştırmanın hazırlandığı zamanda ulaşılabilen kaynaklar ile,

3. Araştırma için ayrılan süre ve maddi imkânlar ile sinırlidir.

\section{YÖNTEM}

$\mathrm{Bu}$ bölümde; araştırmanın modeline, evren ve örneklemine, verilerin toplanması sırasında kullanılan 
yöntemlere ve verilerin çözümlenip yorumlanmasına ayrıntılı bir şekilde yer verilmiştir.

\subsection{Araştırmanın Modeli}

$\mathrm{Bu}$ çalışmada betimsel araştırma yöntemi kullanılmıştır. İlgili belge ve kaynaklara ulaşabilmek için kaynak ve literatür taraması yapılmıştır. Araştırmanın geçerliliğini arttırmak için, probleme dayalı yazılı ve görsel materyaller eklenmiştir.

\subsection{Evren ve Örneklem}

Araştırmanın evrenini Türkiye Radyo ve Televizyon Kurumu (TRT) repertuarında yer alan Hisarlı Ahmet türküleri, örneklemini ise bu türküler arasından seçilen ve klasik kemençe eğitimine uygun olduğu düşünülen beş Hisarlı Ahmet türküsü oluşturmaktadir.

\subsection{Verilerin Toplanması}

Alan yazın taraması yapılarak Türkiye Radyo ve Televizyon Kurumu (TRT) repertuvarı ve diğer yazılı belgeler incelenmiş ve makamsal aktarım, usul aktarımı, sağ ve sol el teknikleri açısından klasik kemençe eğitimine katkı sağlayacağı düşünülen beş Hisarlı Ahmet türküsü seçilmiştir. Bu türkülerin teknik, makamsal öğretim ve usul uygulama seviyeleri düşünülerek, iki aşamada (ileri düzey ve usta icracılık) ele alınmıştır.

\subsection{Verilerin Çözümlenmesi ve Yorumlanması}

Hisarlı Ahmet türkülerinin klasik kemençe ile icra yöntemleri araştırılırken, türkü notaları, videolar, tezler, kitaplar ve belgeler bir araya getirilerek, yöre türkülerinin ezgisel ve yapısal özellikleri ile geleneksel icra biçimleri incelenmiştir. Seçilen türkülerin makam ve usul analizi yapılmış buna uygun olarak sağ ve sol teknikleri belirlenmiştir. Süslemeler, parmak numaraları, yay bağları ve pozisyonlar gösteril- erek türkü notaları 'Mus 2' müzik programında yeniden yazılmıştır. Yapılan bu çalışmalar alanında uzman olan bazı eğitimcilerle paylaşılmış ve onlardan alınan görüşler doğrultusunda gerekli görülen düzeltmeler yapılarak, türküler klasik kemençe eğitiminde kullanılmak için uygun hale getirilmiştir.

\section{BULGULAR VE YORUM}

$\mathrm{Bu}$ bölüm, araştırmanın örneklemini oluşturan beş Hisarlı Ahmet türküsünden oluşmaktadır. Örnek olarak seçilen bu türküler klasik kemençe sağ ve sol el teknikleri ile işlenerek, bu türküleri klasik kemençe eğitim ve konser repertuvarına kazandırmak araştırmanın ana amacı olmuştur. Türkülerin notaları klasik kemençe sağ ve sol el tekniklerini içeren işaretlerle yeniden yazılmış, notaya uygun icrası herkes tarafından ulaşabilmesi için youtube sosyal medya platformuna yüklenmiştir.

Hisarlı Ahmet türkülerinin genellikle zeybek karakterli türküler olmaları ve ege bölgesi türkülerinde kabak kemane sazının kullanılması, türkülerin klasik kemençe ile icrasında benzerlik teşkil etmiş ve Hisarlı Ahmet türkülerini seçilmesinde etkili olmuştur.

Hisarlı Ahmet türküleri klasik kemençe eğitimi açısından iki düzeyde ele alınmıştır. Bu düzeyler değişik üniversitelerdeki alanında uzman öğretim elemanlarının görüşleri dâhilinde oluşturulmuştur. Buna göre "İleri Seviye(Lisans 4.sınıf)" eğitiminde ve "usta icracılık (Lisanüstü)" eğitiminde kullanılabilecek türküler olmak üzere iki bölümde incelenmiştir.

\section{1. İleri Seviye Klasik Kemençe Eğitiminde Çalışılacak Türküler}

Bu bölümde yer alan iki türkü, klasik kemençe eğitiminde lisans son sınıf eğitim repertuvarına alınabilecek niteliktedir. 


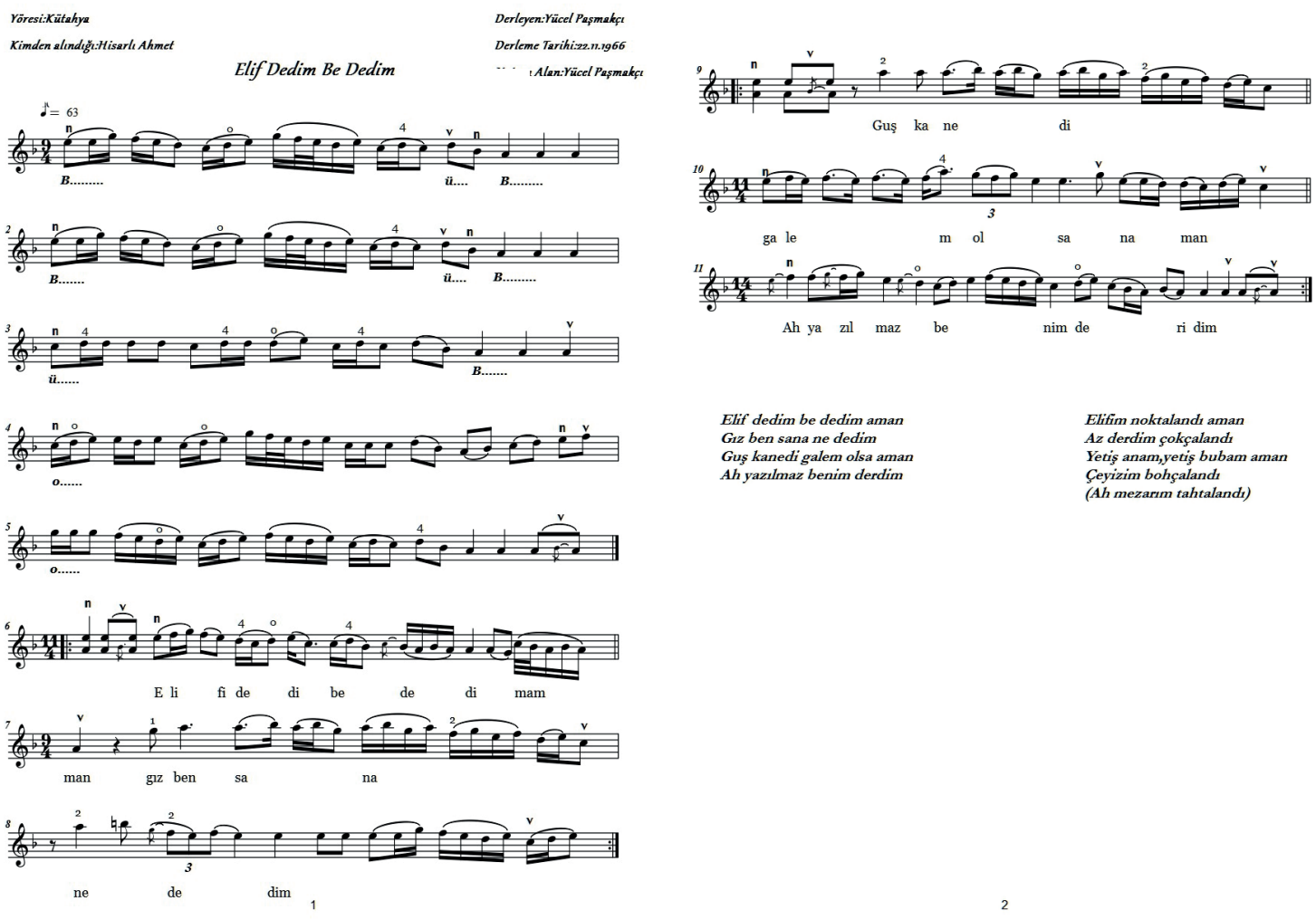

Link:https://www.youtube.com/watch?v=FKD6-H7V4i8 (Kaya, 2021).

\subsubsection{Elif Dedim Be Dedim}

- Sahip olduğu melodik yapı içerisinde muhayyerkürdi makamı dizi seslerini barındırması, bu makam seslerine ve tiz bölgede kullanılan pozisyonlara çalışma imkanı sağlaması,

- Tiz seslerde 'legato' uygulaması ile entonasyon çalışması için imkan sunması,

- 9/4'lük ritim yapısının çalışılmasına (Türkü 9/4'lük 2+2+2+3 ritim kalıbı ile yazılmıştır. Bu ritim kalıbının Klasik Türk Müziği'nde Ağır Aksak usulüne karşılık gelmesi önem taşımaktadır) ve zeybek karakterinin doğru yay kullanımı ile ifadesinin uygulanmasına olanak sağlaması,

- Sahip olduğu uzun sesler sayesinde vibrato çalışmalarına ve yine önemli süsleme tekniklerinden glissandonun çalışılmasına olanak sağlayacak aralıkların var olması,

- Türk Halk Müziği'nde kullanılan aynı seslerin çarpma yapma imkanı sağlamasından dolayı özellikle 3.parmak çarpma, trill ve önden gelen çarpma tekniklerinin uygulanmasına imkan vermesi,

- Türkünün zeybek karakterinden kaynaklanan nüansları, özellikle tiz seslerde pozisyon esnasında uygulama olanağı sağladı̆̆ı için, tiz pozisyonlarda nüans çalışmasına,

- Yay bağ1 (legato), özellikle de bütün yay ve yayın uç kısmının kullanımına olanak sağlaması;

- $\quad$ Sağ ve sol el tekniklerinin üst seviyede çalışılmasina olanak sunması,

- $\quad$ Bu türkünün ileri seviye klasik kemençe eğitimine kazandıracağı kazanımları göstermektedir. Eser kaydı notasyona uygun şekilde icra edilerek, youtube sosyal medya platformuna yüklenmiştir. 


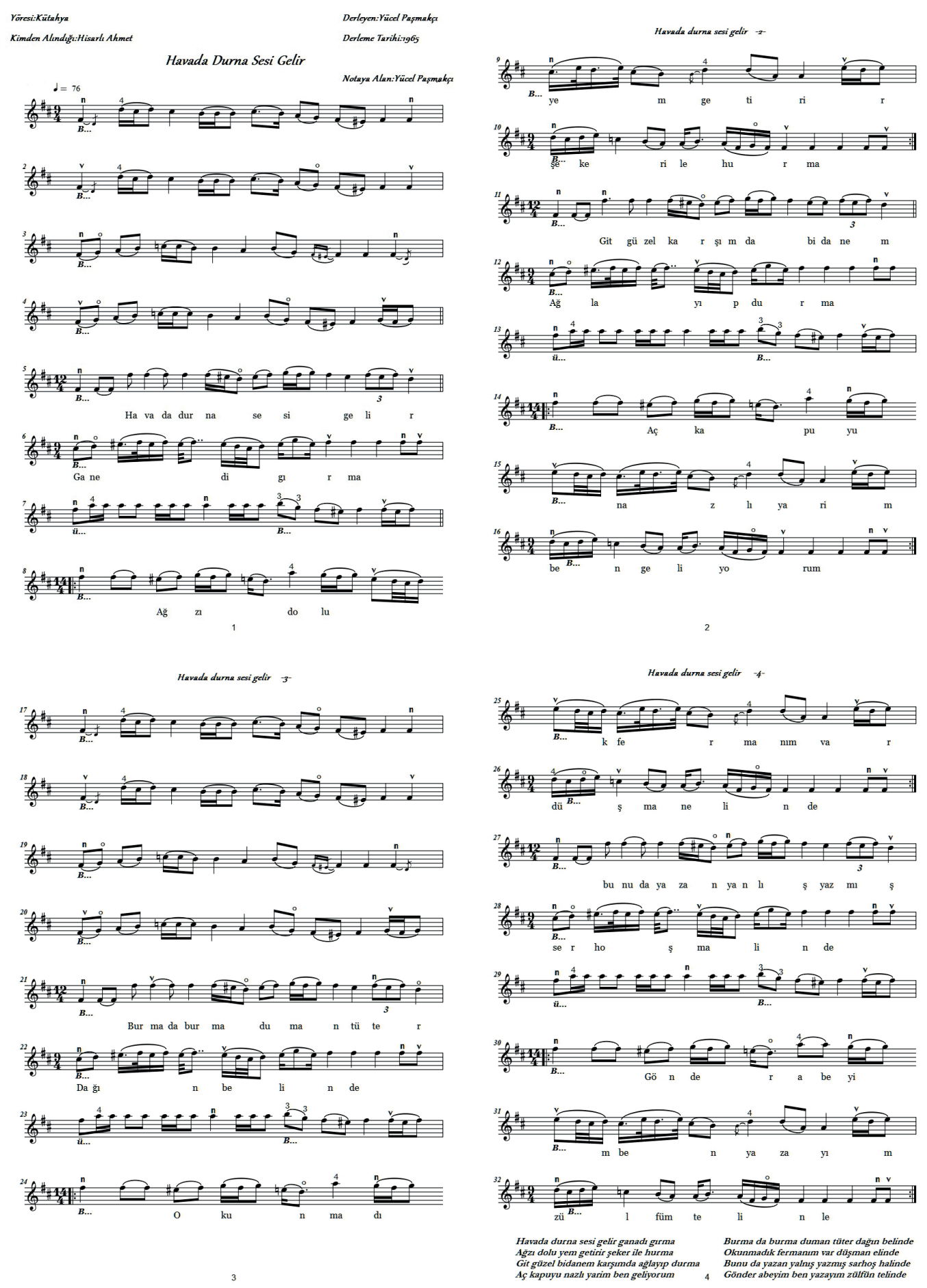

Link:https://www.youtube.com/watch?v=I_7z8tY74uo (Kaya, 2021).

\subsubsection{Havada Durna Sesi Gelir}

- $\quad$ Sahip olduğu melodik yapı içerisinde eviç (evc) makamı dizisi seslerini barındırması dolayısı ile bu makam dizisi seslerine çalışma imkanı sunması (Klasik repertuvarda bu makamda genellikle büyük formda eserlerin olması, bu türkünün evc makamı öğrenimi esnasında yardımcı kaynak olarak kullanılması yararlı olabilir),

- 9/4'lük ritim yapısının çalışılmasına, (Türkü 9/4'lük 2+2+2+3 ritim kalıbı ile yazılmıştır. Bu rit- im kalıbının Klasik Türk Müziği'nde Ağır Aksak usulüne karşılık gelmesi önem taşımaktadır) ve zeybek karakterinin doğru yay kullanımı ile ifadesinin uygulanmasına olanak sağlaması,

- Sahip olduğu uzun sesler sayesinde vibrato ve yine önemli süsleme tekniklerinden glissandonun çalışılmasına,

- Türk Halk Müziği'nde kullanılan aynı seslerin çarpma yapma imkanı sağlamasından dolayı özellikle 3.ve 4.parmak çarpma çalışmalarına, 
- Yay bağ1 (legato), özellikle de bütün yay ve yayın uç kısmının kullanımına olanak sağlaması;

- $\quad$ Bu türkünün ileri düzey klasik kemençe eğitimine kazandıracağı kazanımları göstermektedir. Eser kaydı notasyona uygun şekilde icra edilerek, youtube sosyal medya platformuna yüklenmiştir.

\subsection{Usta İcracılık Eğitiminde Çalışılacak Türküler}

$\mathrm{Bu}$ bölümde yer alan üç türkü, klasik kemençe lisansüstü eğitim ve konser repertuvarına alınabilecek niteliktedir. Bu türkülerin usta icracılık düzeyinde ele alınmasının en önemli sebebi uygulanan sağ ve sol el tekniklerinin üst seviye zorlukları içermesidir. Sazda teknik hakimiyete sahip olduktan sonra icracının tavır ve uslüp çalışması gerekir. İşte tam bu aşamada bu türküler hem makamsal ses unsurları, hem ritmik yapıları hem de karakteristik ezgileri ile icralarında zeybek tavrını ve kişinin kendi üslubunu aktarabileceği zemini sağlamaktadır. Bir klasik kemençe resitalinde böyle bir türküyü layıkıyla icra etmek usta icracıllk gerektirir. Bu durumda bu türkülerin klasik kemençe eğitimine kazandırdıkları çok kıymetlidir.

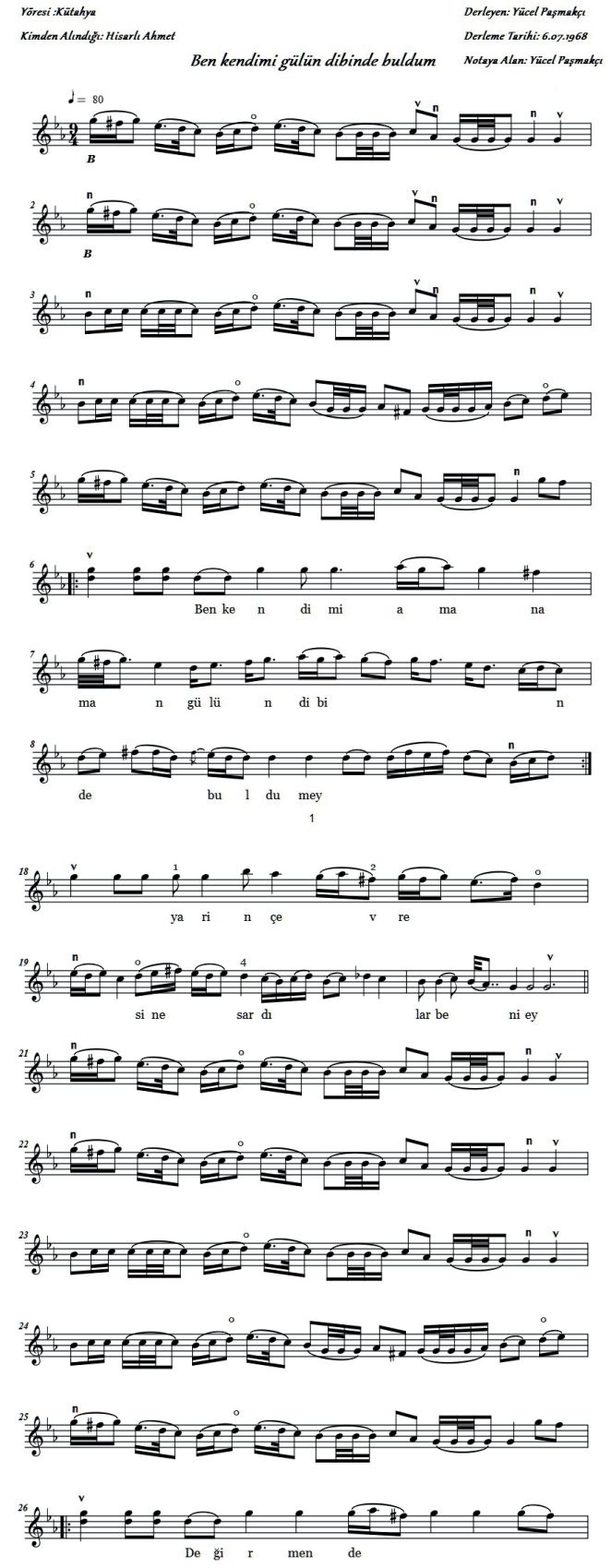

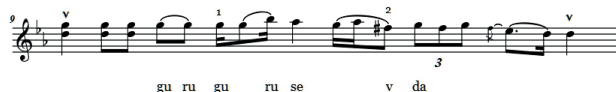
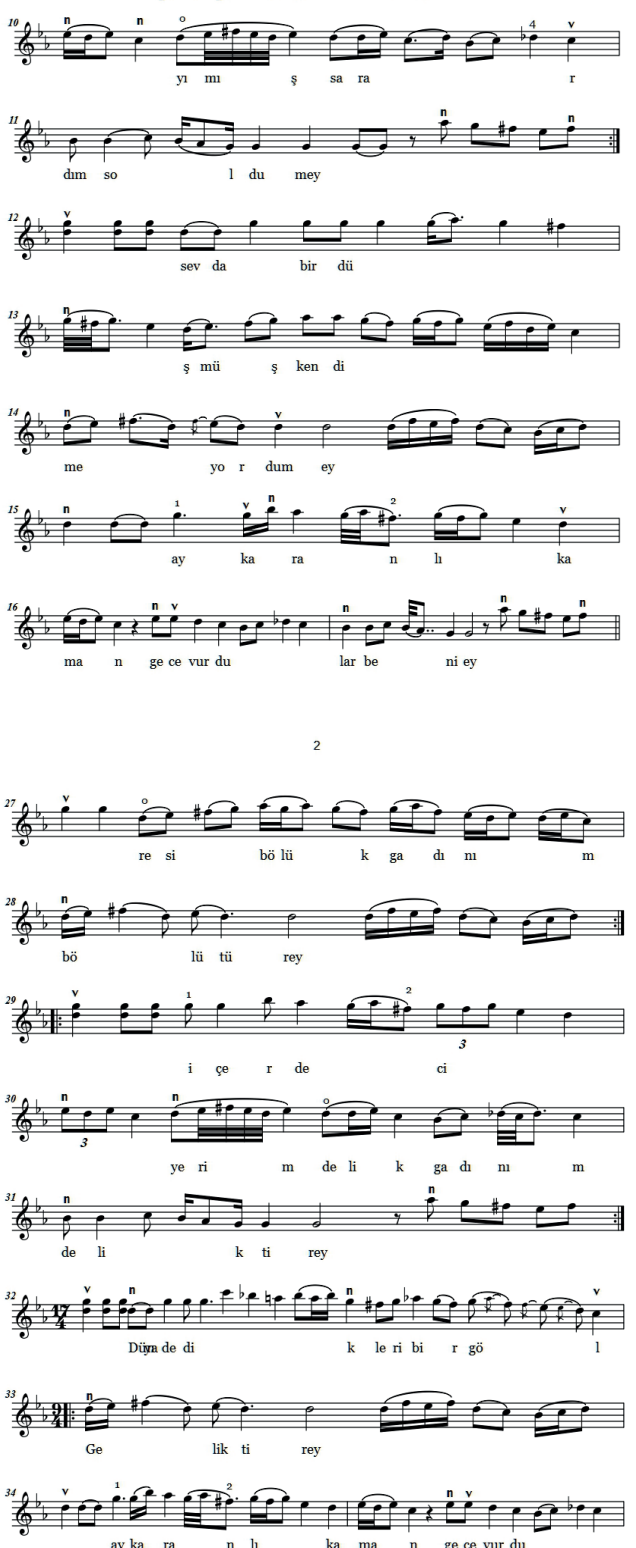


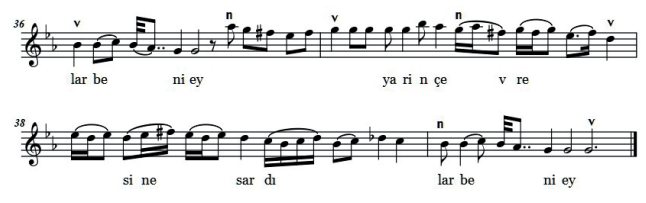

Link:https://www.youtube.com/watch?v=FBBQ6cISOyc (Kaya, 2021).

\subsubsection{Ben Kendimi Gülün Dibinde Buldum}

- Türkünün hicazkar makamı dizisi seslerine sahip olması sebebi ile bu seslerin çalışılması,

- Tiz seslerde farklı yay teknikleri kullanarak entonasyon çalışmasına imkan sağlamasın,

- $\quad$ 9/4 ritim yapısının çalışılmasına olanak sağlaması (Türkü 9/4'lük 2+2+2+3 ritim kalıbı ile yazılmıştır. Bu ritim kalıbının Klasik Türk Müziği'nde Çifte Sofyan usulüne karşılık gelmesi önem taşımaktadir),

- Zeybek karakterini yay, glissando ve çarpmalarla ifade etme çalışmasına olanak sağlaması,

- Yay bağ1 (legato), özellikle nüans kullanarak bütün yay kullanımına imkan sunması,

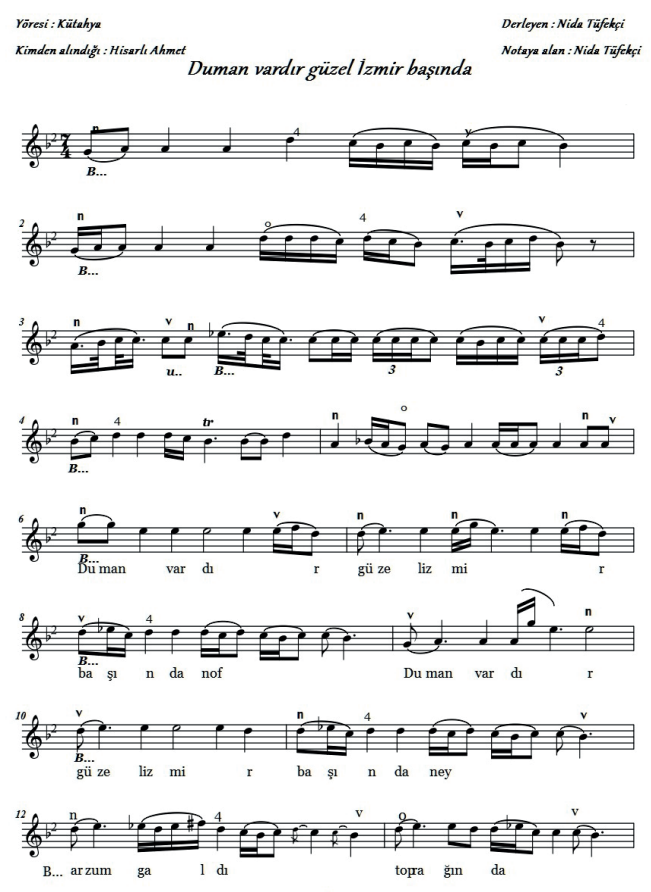

- Klasik kemençe sazında önemli bir yer arz eden süsleme tekniklerinden glissandonun çalışılmasına,

- Türk Halk Müziği'nde ardı ardına kullanılan aynı seslerin yay bağı kullanılarak çalındığında bir üst sesle çarpma yapma imkanı sağlamasından dolayı çarpma ve trill çalışmalarına olanak sağlaması;

- Tavir ve üslup çalışmasına uygun oluşu(Zeybek tavrının ve kişinin kendi üslubunun ortaya konması bakımından),

- $\quad$ Bu türkünün klasik kemençe usta icracılık eğitimine kazandıracağı kazanımları göstermektedir. Eser kaydı notasyona uygun şekilde icra edilerek, youtube sosyal medya platformuna yüklenmiştir.
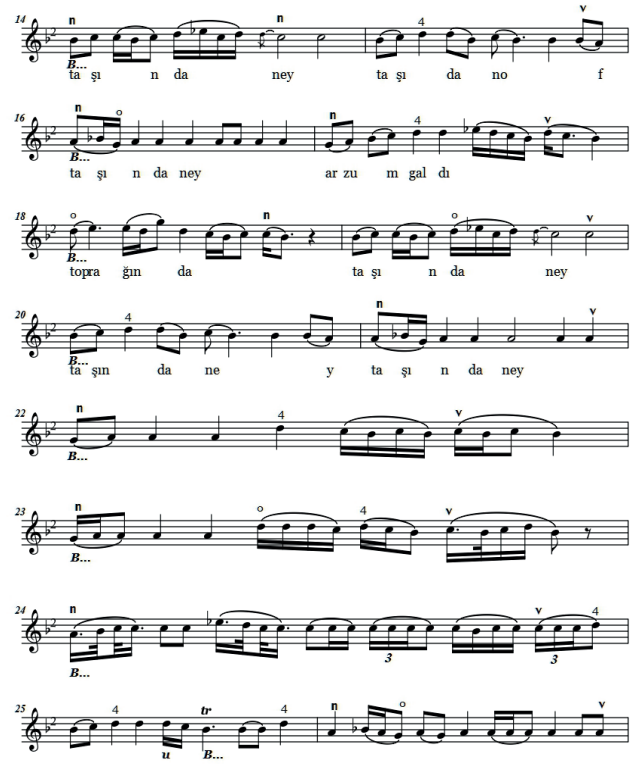


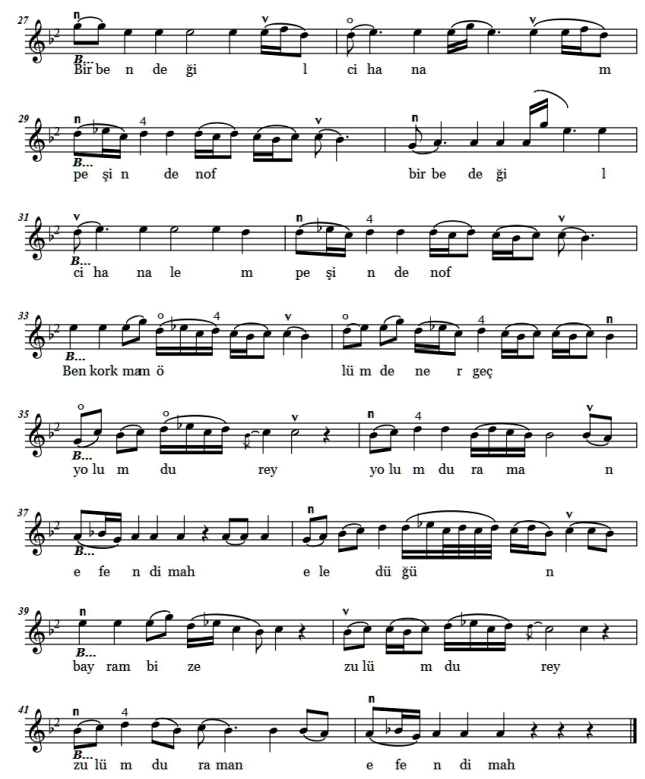

Link:https://www.youtube.com/watch?v=ZcnY8lhaR9A (Kaya, 2021).

\subsubsection{Duman Vardır Güzel İzmir'in Başında}

- $\quad$ Sahip olduğu melodik yapı ile uşşak ve hüseyni çeşnilerinin çalışılmasına ve Klasik Türk müziğinde önemli bir yer teşkil eden segâh sesinin çalışılmasına,
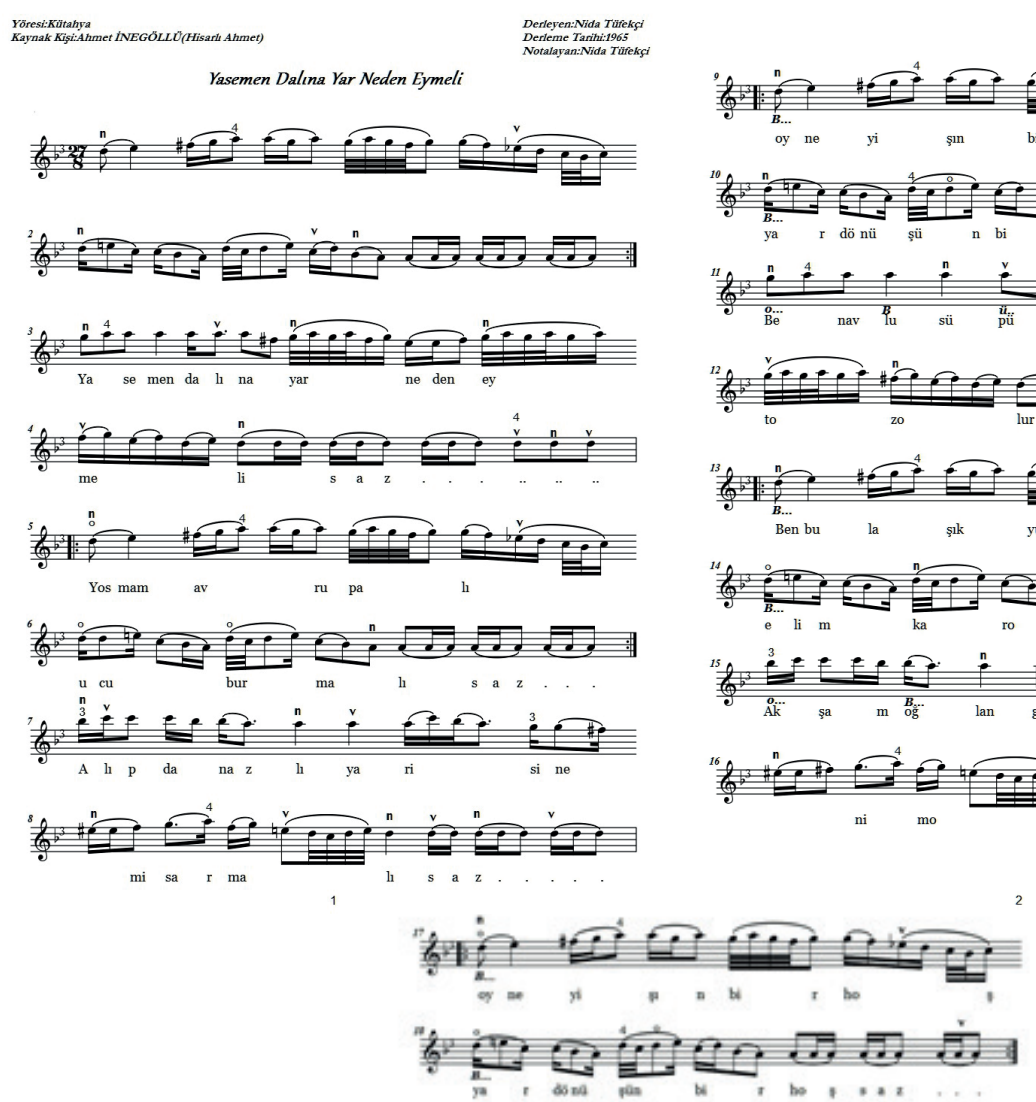

Link: https://www.youtube.com/watch?v=aBdJx392svI (Kaya, 2021).
- $7 / 4$ lük ritim yapısının çalışılmasına (Türkü 7/4'lük3+2+2 ritim kalıbı ile yazılmıştır. Bu ritim kalıbının Klasik Türk Müziği'nde Devr-i Hindi usulüne karşılık gelmesi önem taşımaktadır) ,

- Klasik kemençe süsleme tekniklerinden; Sahip olduğu uzun sesler sayesinde vibrato çalışmalarına,

- Kemençe sazında her aşamada icrası zor olan 4.parmak çarpması ve diğer seslerde yapılan çeşitli çarpma çalışmalarına,

- Ezgisel yapısındaki uzun seslerde trill çalışmalarına,

- Yay bağı(legato), özellikle nüans kullanarak bütün yay kullanımına,

- Melodi yapısındaki si (bir koma) segah sesinden si (beş koma) kürdi sesine geçişlerde ve mi (hüseyni) sesinden, mi (beş koma) nim hisar sesine geçişlerdeki glisanda ve trill çalışılmasına olanak sağlaması;

- Bu türkünün klasik kemençe usta icracılık eğitimine kazandıracağı kazanımları göstermektedir. Eser kaydı notasyona uygun şekilde icra edilerek, youtube sosyal medya platformuna yüklenmiştir.
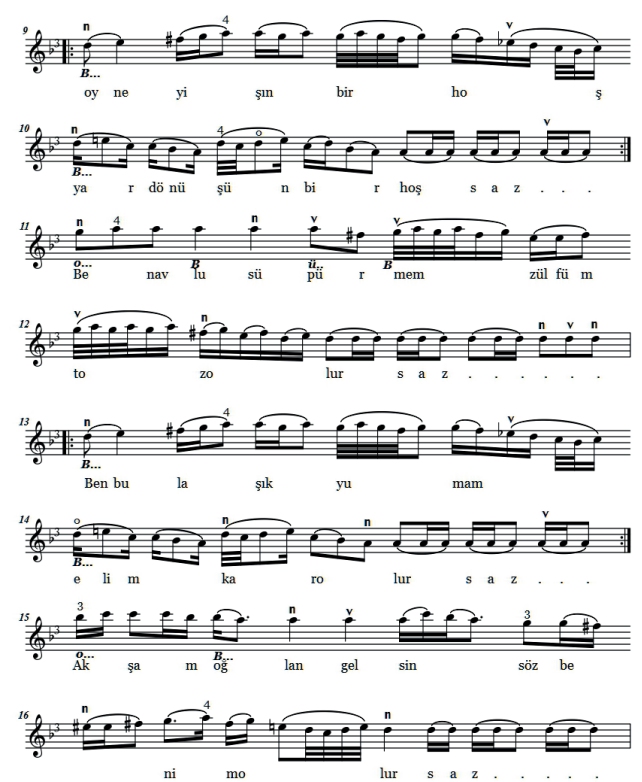


\subsubsection{Yasemen Dalına Yar Neden Eymeli}

- Sahip olduğu melodik yapı içerisinde 'karcığar makamı' dizisi seslerini barındırmasından dolayı, bu makamın dizi seslerine çalışılmasına

- Tiz bölgede kullanılan seslerde entonasyon çalışmasına,

- Farklı yay teknikleri ile pozisyonlara çalışmalarına imkanı sunması,

- 27/8'lik nadir rastlanan bir ritim yapısını tanıma firsatı yaratması ve bu ritme uygun yay kullanımını tecrübe etmesi,

- Türk Halk Müziği'nde ardı ardına kullanılan aynı seslerin yay bağı kullanılarak çalındı̆̆ında bir üst sesle çarpma yapma imkanı sağlamasından dolayı 1., 3. ve 4.parmak çarpma ve trill çalışmalarına,

- Yay bağ1 (legato), özellikle de 5-6 sesi içeren yay bağları ile bütün yay ve ayrı yaylarla yayın uç kısmının kullanımına olanak sağlaması,

- $\quad$ Sahip olduğu melodik yapı ile kemençede kullanımı zor olan 4. Parmak için egzersiz sayılabilecek bir yapıya sahip olması,

- Türkünün hem entonasyon, hem teknik hem de üslup ve tavır açısından çalışılmasına ve kişinin kendi üslubunu aktarabilmesine zemin sağlaması

- Bu türkünün klasik kemençe usta icracılık eğitimine kazandıracağı kazanımları göstermektedir. Eser kaydı notasyona uygun şekilde icra edilerek, youtube sosyal medya platformuna yüklenmiştir.

\section{SONUÇ VE ÖNERİLER}

Bu çalışmada Hisarlı Ahmet'e ait beş türkü seçilmiş, klasik kemençeye özgü notasyonları yazılmış, türkülerin örnek icraları yapılmıştır. Buna göre ortaya çıan sonuç ve önerileri şöyle sıralayabiliriz;

Klasik kemençe eğitiminde halk ezgilerimizden faydalanmak mümkündür.

Hisarlı Ahmet'e ait beş türkü klasik kemençeye özgü notasyonları yazılarak ve örnek icraları yapılarak klasik kemençe eğitimi dağarına kazandırılmıştır.

Seçilen türküler, teknik ve artistik açıdan değerlendirildiğinde, klasik kemençe eğitiminde ileri seviye ve usta icracılık eğitiminde kullanılması önerilmiştir.
Bu çalışmada, türkülerin bazı bölümleri süsleme tekniklerinden olan çarpma, glissando, vibrato ve trill çalışmalarında etüt görevini görmüştür.

Çalışmada incelediğimiz türküler, klasik kemençede farklı yay kullanım tekniklerinin çalışılmasına olanak sağlamıştır.

Türkülerin ritim yapılarının icraya yansıtılmasında nüans çalışmalarına imkan sağlaması, öğrencinin yay hakimiyetine ve kişisel icrasına çok önemli katkılar sağlayacaktır.

Çalg1 eğitiminde türkülerden faydalandığımızda öğrenci, Türk halk müziği ritim ve ezgi yapısına aşina olur ve bunu icrasına yansıtmayı öğrenir. Hisarlı Ahmet türkülerinin geneli zeybek karakterli türküler olduğu için öğrenci zeybek ezgilerine, ritimlerine ve vurgularına aşina olacaktır.

Türk halk müziğinin zeybek karakterli türkülerinin icrasında klasik kemençe sazını kullanmak teknik açıdan mümkündür.

Çalışmada usta icracılık eğitimi için önerilen türküler, klasik kemençe eğitimindeki son aşama olan tavır ve üslup kazanma becerisi için çok değerli katkılar sunmaktadır.

Türkülerin klasik kemençe ile icrası ortaya hoş bir tını ve icra farklılı̆̆ getirmiştir.

Seçilen türküler klasik kemençe eğitim sürecinde belirtilen düzeyde, klasik büyük formdaki eserler öncesinde makam seslerine alışmak için yardımcı parça olarak kullanılabilirler.

$\mathrm{Bu}$ çalışma bağlamında klasik kemençe eğitiminin çeşitli aşamalarında farklı yörelerin veya aşıkların türküleri de kullanılabilir.

Hisarlı Ahmet türkülerinin teknik ve artistik açıdan zenginliği ve icra eden kişiye, kendine ait bir tavır yaratma imkanı sunması, konser repertuvarlarında değerli bir dağarcık oluşturabilir.

Bu çalışmadan yola çıkarak alan dışı farklı eserleri de klasik kemençe eğitiminde kullanma fikri geliştirile bilinir.

Mesleki çalgı eğitiminde farklı materyallere, farklı fikirlere farklı yaklaşımlara yer vermek eğitimin gelişmesine katkı sağlayabilir.

Avrupa Müziği'nde olduğu gibi çalgıya özel nota yazımı bizim çalgılarımız için de yaygınlaştırılabilir. 
Bu hem eğitmen açısından, hem de öğrenci açısından çok değerli olacaktır.

Usta icracılık için çalgıya özel konser repertuvarları oluşturula bilinir ve bu aşamada alan dışı eserlerden de faydalanılabilinir.

$\mathrm{Bu}$ çalışma bir öneri niteliğinde olup ileride diğer sazlar için de benzer uygulamaların yapılması için örnek teşkil edecek niteliktedir.

\section{KAYNAKÇA}

DEMIRBATIR, R.E. (1998). Türkiye'deki Eğitim Fakülteleri Müzik Eğitimi Bölümlerinde Viyolonsel Eğitimi, Yayımlanmamış Doktora Tezi, Gazi Üniversitesi Fen Bilimleri Enstitüsü.

ERTÜRK, S. (1979). Eğitimde Program Geliştirme. Ankara: Yelkentepe Yayınları, 3. Bask1, 9786055152024

HISARLI, M. (2009). Hisarl Ahmet Kimdir?, Hisarl Ahmet ve Türküleri Sетроzуити. 10 Ocak 2009 Kütahya. Kütahya: Kütahya Güzel Sanatlar Derneği, 137-143.

KANT, I. (2006). Eğitim Üzerine. Çeviren: Ahmet Aydoğan. İstanbul: İz Yayınc1lık, 1.Bask1,9789753556262.

KAYA, F. (2020). Elif Dedim Be Dedim-Hisarlı Ahmet, youtube.com/c/flzflz125, https:/www.youtube.com/watch?v=FKD6-H7V4i8 [Erişim tarihi; $15 / 03 / 2021]$

KAYA, F. (2020). Havada Durna Sesi Gelir-Hisarlı Ahmet, youtube.com/c/ flzflz125, https://www.youtube.com/watch?v=I 7z8tY74uo [Erișim tarihi: $15 / 03 / 2021]$

KAYA, F. (2020). Ben Kendimi Gülün Dibinde Buldum-Hisarlı Ahmet, youtube.com/c/flzflz125, https://www.youtube.com/watch?v=FBBQ6cISOyc [Erişim tarihi: 15/03/2021].

KAYA, F. (2020). Duman Vardı Güzel İzmir'in Başında-Hisarlı Ahmet, youtube.com/c/flzflz125, https://www.youtube.com/watch?v=ZcnY8lhaR9A [Erişim tarihi: 15/03/2021].

KAYA, F. (2020). Yasemen Dalına Yar Neden Eymeli-Hisarlı Ahmet, youtube.com/c/flzflz125, https://www.youtube.com/watch?v=aBdJx392svI [Erişim tarihi: 15/03/2021].

ÖZCAN, N. (1995). "Meşk". Türkiye Diyanet Vakfi İslâm Ansiklopedisi. c. XXIX, ss:374, Ankara: Türk Diyanet Vakfı Yayınları, 1.Bas$\mathrm{k}_{1}, 9789753894159$

SERIN, M. (1995) "Meșk". Türkiye Diyanet Vakfi İslâm Ansiklopedisi. c. XXIX, ss:375, Ankara: Türk Diyanet Vakfı Yayınları, 1.Bask1, 9789753894159

ŞENEL, S. (1995) "Halk Musikisi". Türkiye Diyanet Vakfi İslâm Ansiklopedisi. c. XXV, ss:354, Ankara: Türk Diyanet Vakfı Yayınları, 1.Bas$\mathrm{k}_{1}, 9789753894159$

TÜRKMEN, U. (2013). Hisarl Ailesi "Mustafa Hisarl ve Kütahya Türküleri”. Kütahya: Kütahya Belediyesi Kültür Yayınları, 1.Bask1, 9786056105661.

UÇAN, A. (1997). Müzik Ĕğitimi/Temel Kavramlar, İlkeler, Yaklaşımlar. Ankara: Müzik Ansiklopedisi Yayınları, 2.Bask1,9789757436164.

YAHYA, G. (1997). Türk Çalgı Musikisinin Geliştirilmesi Üzerine Görüs ve Öneriler, 4. Türk Müziği Günleri-Türk Müziğinde Eğitim Sempozyumu, 15-16 Mayıs 1997 İstanbul. İstanbul: T.C. Kültür Bakanlığı Yayınları,70-74, 9751719321.

YALTIRIK, H. (2009) Hisarlı Ahmet İnegöllü'nün Bağlamasında Tavır ve
Özay Gönlüm'e Etkisi, Hisarll Ahmet ve Kütahya Türküleri Sempozyumu. 10 Ocak 2009 Kütahya. Kütahya: Kütahya Güzel Sanatlar Derneği,80-84. 